\title{
142. Lepidolina Problem: Final Remarks
}

\author{
By Hisakatsu YABE, M.J.A.
}

(Comm. June 13, 1966)

J. S. Lee $(1934)^{1)}$ established Lepidolina as a genus distinct from Yabeina Deprat (1924), ${ }^{2)}$ stating "Consolidation of septa and septula takes place almost in the first whorl, and the wall is almost entirely devoid of the keriotheca", and also from Sumatrina Volz $(1904),{ }^{3)}$ in which "all the septa and septula are short and straight." He beleived that Lepidolina was derived from Yabeina.

The genotype of Lepidolina is Neoschwagerina (Sumatrina) multiseptata Deprat, originally from Cambodia.4) Lee referred specially to this species described by J. Deprat from Akasaka, Japan, and illustrated a specimen in thin section from Kweichow, China, which "in high magnification still reveals an exceedingly thin keriotheca attached here and there to the tectum".5)

Deprat $^{6)}$ reported on his find of well preserved specimens of Sumatrina multiseptata from the uppermost fusulinid zone of the Akasaka Limestone. However, subsequent Japanese paleontologists including Y. Ozawa ${ }^{7}$ and S. Hanzawa ${ }^{8)}$ failed to obtain any indisputable specimens of this species, and in consequence, they have been for a long time sceptical of its real occurrence in the Akasaka Limestone, until R. Morikawa and Y. Suzuki ${ }^{9)}$ found their Yabeina cfr. multiseptata from the Yabeina igoi zone of the Limestone, which is, according to the authors, closely similar to that named species in the details of the microstructure though provided with a proloculum of small size, and suspected it to be the microspheric form of that species. S. Hanzawa, ${ }^{10)}$ on the contrary, regarded it to be nothing but Yabeina globosa, probably on account of the minute proloculum, and also because, "we sometimes encounter with some specimens of Yabeina globosa and Neoschwagerina katoi (Pl. 11, Fig. 1) from Akasaka, in which the septa and septula as well as sometimes, the spirotheca are thin and consolidation of the kerothecal structure of them is remarkably advanced". At present the writer has no knowledge for deciding which of the two specific interpretations is correct, but he beleives it is premature to completely disregard Deprat's report on the occurrence of Yabsina (Lepidolina) multiseptata from the Akasaka Limestone. According to Deprat, ${ }^{11}$ this species exists in association with Fusulina granum-avenae Roemer, and Verbeekina douvillei Deprat, in a horizon higher than 
the Yabeina globosa zone, and hence highest of all the fusulinid zones in the Limestone. Namely, he stated "Énfin en arrière encore et stratigraphiquement plus haut, j'ai retrouver dans les calcaires gris ma belle espèces Cambodge, Neoschwagerina (Sumatrina) multiseptata, ...". It is highly probable that he did not actually observe the limestone with multiseptata directly overlying another with Yabeina inouyei. Pseudofusulina granum-avenae being now known only from the lowest zone of the Akasaka Limestone, it allows an assumption that the sample of limestone of Deprat is a limestone breccia, or conglomerate of much younger date.

One year earlier, Morikawa ${ }^{12}$ referred Yabeina kaisensis Huzimoto $\left.^{13}\right)$ from near Kaise, Minami-Saku-gun, in the northwestern part of the Kanto Mountainland, as specifically indistinguishable from his Yabeina cfr. multiseptata from the Akasaka Limestone. According to Huzimoto, there is exposed near Kaise a $500 \mathrm{~m}$ thick formation consisting of in descending order:

Sandstone, shale and chert in alternation

Limestone

Gray and red cherts interbedding graywacke.

The limestone, $7 \mathrm{~m}$ thick, yielded

Neoschwagerina craticulifera (Schwager)

N. douvillei Ozawa

Yabeina globosa (Yabe)

$Y$. $\quad$ kaisensis Huzimoto

The fusulinid here named Yabeina globosa requires a more critical examination, since the writer is verbally informed by M. Murata that it reminds one of Yabeina (Lepidolina) shiraiwensis Ozawa in certrain features.

Neoschwagerina globosa Yabe (1906) ${ }^{14}$ is a common fusulinid in the upper division of the Akasaka Limestone, but was not described sufficiently and led later authors to misconception. For instance, $N$. globosa of H. Douville, ${ }^{15)}$ Deprat, ${ }^{16)}$ and M. Colani ${ }^{17)}$ from Indochina shows a different form, subsequently named Neoschwagerina douvillei by Y. Ozawa. ${ }^{18)}$ Further he first recognized the specific identity of N. globosa Yabe and Yabeina inouyei Deprat, ${ }^{19)}$ a view which is now generally accepted by Japanese paleontologists. Very lately, however, Morikawa and Suzuki ${ }^{20)}$ while dealing with fusulinids from the Akasaka Limestone, held the two as distinct species, the Yabeina inouyei characterized by "larger size, shorter protrusion of keriotheca and longer apparently secondary transverse septula". Further, $Y$. inouyei is stated to occur in a zone higher than $Y$. globosa. Unfortunately, $Y$. inouyei is not well illustrated in Plate 22 accom- 
panying their paper.

The diagrammatic sketch by Deprat of $Y$. inouyei (Text-Fig. 6) and one of the best axial sections cut through or near the proloculum (Pl. Vl, Fig. 4) shows an inflated fusiform individium respectively. Shorter protrusion of the keriotheca and high parachomata in axial section is well shown by Pl. XXVlll, Fig. 12 in Colani's report, cited afore.

Some of the axial sections of $Y$. globosa and $Y$. inouyei are much elongated, and there are several forms intermediate between the form ratio 1 and 1.5, illustrated by several authors; some of them may be due to secondary deformation.

The stratigraphical relation of individuals varied in form and in the degree of reduction of the keriotheca are not definitely known at present. For a while, the writer assuming the specific identity of Neoschwagerina globosa and Yabeina inouyei, finds it best to designate the two different form-types,

Yabeina globosa globosa Yabe. for nearly spherial type

Yabeina globosa inouyei Deprat, for inflated fusiform type

The genotype of Yabeina Deprat is Y. globosa inouyei Deprat.

\section{References}

1) Lee, J. S. (1934): Taxonomic criteria of Fusulinidae, with notes on seven new Permian genera. Mem. Nat. Research Inst., No. 14, p. 21 (Pl. IV, Figs. 2, 3).

2) Deprat, J. (1914): Étude comparative des Fusulinidés d'Akasaka (Japon) et des Fusulinides de Chine et d'Indochine. Mém. Serv. Géol. Indochine, 3 (1), 30 .

3) Volz, W. (1904): Zur Geologie von Sumatra. Geol. Pal. Abh., NF. 6 (2), Anhang, Einige neue Foraminiferen, Korallen, sowie Hydrokorallen aus dem Oberkarbon Sumatras., p. 182.

4) Deprat, J. (1912): Étude des Fusulinides de Chine et d'Indochine, Classifikation des Calcaires a Fusulinides. Mém. Serv. Géol. l'Indochine. 5 (3), p. 53 (Pl. III, Figs. 2-8).

5) Lee, J. S. (1934): Loc. cit., Pl. III, Fig. 3 (explanation).

6) Deprat, J. (1924): Loc. cit., p. 34 (Pl. V, Figs. 7-11).

7) Ozawa, Y. (1927). Stratigraphical studies of the Fusulina limestone of Akasaka, Province of Mino. Jour. Fac. Sci., Imp. Univ. Tokyo, ser. II, 2 (3), p. 134.

8) Hanzawa, S., and M. Murata (1963): The paleontologic and stratigraphic considerations on the Neoschwagerininae and Verbeekininae, with the descriptions of some fusulinid Foraminifera from the Kitakami Massif, Japan. Sci. Rep. Tôhoku Univ. ser. 2, 35 (1), 2.

9) Morikawa, R., and Y. Suzuki (1963): Fusulinids from the Akasaka Limestone (part 2). Sci. Rep. Saitama Univ., ser. B, 4 (1), 66 (Pl. 9, Fig. 4; Pl. 14, Fig. 10).

10) Hanzawa, S., and Murata, M. (1963): Loc. cit.

11) Deprat, J. (1924): Loc. cit., p. 6. 
12) Morikawa, R. (1962): A solidgraphic study of fusulinid Foraminifera. Sci. Rep. Saitama Univ., ser. B, 4 (2), 144 (footnote).

13) Huzimoto, H. (1936): Stratigraphical and palaeontological studies of the Titibu System Kanto Mountainland. Sci. Rep., Tokyo Bunrika Daigaku, ser. C, 1 (2).

14) Yabe, H. (1906): A contribution to the genus Fusulina. Jour. Coll. Sci. Imp. Univ. Tokyo, Vol. 21, art 5, p. 4.

15) Douvillé, H. (1906): Les calcaires à Fusulines de l'Indochine. Bull. Soc. Géol. France sér. 4, Vol. 6.

16) Deprat, J. (1912): Loc. cit., p. 51 (Pl. IV, Figs. 1-4). (1914): Loc. cit., p. 29.

17) Colani, M. (1924): Nouvelle Contribution a l'etude des Fusulonides de l'Extreme Orient. Mém. Serv. Géol. L'Indochine, No. 11, 152 (Pl. XXIII, Figs. 1, 2, 4-14, 22-34, 36-38; Pl. XXIII, Figs. 9. 13 a, b, c; Pl. XXV, Figs. 913).

18) Ozawa, Y. (1925): Paleontological and stratigraphical studies on the PermCarboniferous limestone of Nagato. Pt. II, Paleontology. Jour. Coll. Sci. Imp. Univ. Tokyo, Vol. 45 (Art. 6, p. 55, Pl. XI, Figs. 5-7).

19) Deprat, J. (1914): Loc. cit., pp. 39-34 (Pl. VI, Figs. 4-19; Pl. VIII, Figs. 1, 2); Colani, M. (1924): Loc. cit., pp. 125, 156 Pls.

20) Morikawa, R., and Y. Suzuki (1961): Loc. cit., pp. 67, 69, 70. 